\title{
Characterization of tumor antigen peptide-specific $T$ cells isolated from the neoplastic tissue of patients with gastric adenocarcinoma
}

\author{
Amedeo Amedei $\cdot$ Elena Niccolai $\cdot$ Chiara Della Bella $\cdot$ Fabio Cianchi $\cdot$ \\ Giacomo Trallori · Marisa Benagiano $\cdot$ Lapo Bencini $\cdot$ Marco Bernini • \\ Marco Farsi · Renato Moretti · Gianfranco Del Prete · Mario Milco D'Elios
}

Received: 4 November 2008 / Accepted: 4 March 2009 / Published online: 25 March 2009

(C) Springer-Verlag 2009

\begin{abstract}
Gastric cancer is a significant cause of morbidity and mortality worldwide. Surgical resection remains the primary curative treatment for gastric adenocarcinoma, but the poor (15-35\%) survival rate at 5 years has prompted many studies for new therapeutic strategies, such as specific immunotherapy. The aim of this study was to analyze the functional properties of the $\mathrm{T}$ cell response to different antigen peptides related to gastric cancer in patients with gastric adenocarcinoma. To this purpose, we have cloned and characterized tumor-infiltrating T cells (TILs) isolated from the neoplastic gastric tissue samples. A T cell response specific to different peptides of gastric cancer antigens tested was documented in 17 out of 20 patients, selected for their
\end{abstract}

\footnotetext{
A. Amedei $(\bowtie) \cdot$ E. Niccolai $\cdot$ C. D. Bella $\cdot$ M. Benagiano ·

G. Del Prete · M. M. D'Elios

Department of Internal Medicine,

University of Florence, Viale Morgagni 85,

50134 Florence, Italy

e-mail: aamedei@unifi.it
}

\author{
A. Amedei · E. Niccolai · C. D. Bella $\cdot$ M. Benagiano \\ G. Del Prete · M. M. D'Elios \\ Department of Biomedicine, \\ Azienda Ospedaliera Universitaria Careggi (AOUC), \\ Viale Morgagni 85, 50134 Florence, Italy \\ F. Cianchi \\ Department of Medical and Surgical Critical Care, \\ University of Florence, Viale Morgagni 85, 50134 Florence, Italy \\ G. Trallori \\ Gastroenterology Unit, AOUC, \\ Viale Morgagni 85, 50134 Florence, Italy \\ L. Bencini · M. Bernini · M. Farsi · R. Moretti \\ Division of General and Oncologic Surgery, \\ Department of Oncology, AOUC, \\ Viale Morgagni 85, 50134 Florence, Italy
}

HLA-A02 and/or -A24 alleles. Most of the cancer peptidespecific TILs expressed a Th1/Tc1 profile and cytotoxic activity against target cells. The effector functions of cancer peptide-specific $\mathrm{T}$ cells obtained from the peripheral blood of the same patients were also studied. The majority of peripheral blood peptide-specific $\mathrm{T}$ cells also expressed the Th1/Tc1 functional profile. In conclusion, in most of the patients with gastric adenocarcinoma, a specific type- $1 \mathrm{~T}$ cell response to gastric cancer antigens was detectable and would have the potential of hamper tumor cell growth. However, in order to get tumor cell killing in vivo, the activity and the number of cancer peptide-specific Th1/Tc1 cells probably need to be enhanced by vaccination with the appropriate cancer antigenic peptides or by injection of the autologus tumor peptide-specific T cells expanded in vitro.

Keywords Gastric adenocarcinoma .

Tumor-infiltrating lymphocytes $\cdot$ Th1/Tc1 ·

Gastric cancer antigen-associated peptides
Abbreviations
GCAA Gastric cancer antigen-associated peptides
PBMC Peripheral blood mononuclear cells
Th1 and Th0 Type 1 and type 0 helper $\mathrm{CD}^{+} \mathrm{T}$ cells
$\mathrm{Tc} 1$ and $\mathrm{Tc} 0$ Type 1 and type 0 cytotoxic $\mathrm{CD} 8^{+} \mathrm{T}$ cells
TILs Tumor-infiltrating lymphocytes

\section{Introduction}

Gastric cancer is a significant cause of morbidity and mortality worldwide [11]. It remains the second most frequently diagnosed cancer in the world, accounting for $10 \%$ of all new cancer diagnoses. It has been estimated that there will be more than 870,000 deaths for this disease in 
the year 2010, accounting for approximately $12 \%$ of all cancer deaths [20].

Gastric cancer is the end result of the interplay of many risk factors as well as of protective factors. Genetic and environmental elements are likely to play a role in the etiology of the disease. Several factors are suspected to play a role in gastric carcinogenesis, including the effects of diet, e.g., the low intake of animal fats and proteins is associated with a decreased risk of cancer development [25]. Infectious agents, particularly Helicobacter pylori, may also play a role $[14,42]$. H. pylori-mediated events, such as production of reactive oxygen radicals, activation of growth factors and cytokines, and alterations of signal transduction processes are potential risk factors for gastric adenocarcinoma [35, 41]. Hereditary elements increase as well the risk of gastric cancer and this malignancy is part of a number of familial cancer syndromes, the most celebrated case being Napoleon Bonaparte [24]. Also the polymorphism of Interleukin(IL)-1 $\beta$ and IL-8 genes has been associated with increased risk of gastric cancer $[10,40]$.

Surgical tumor resection remains the primary curative treatment for gastric cancer. Nevertheless, the overall 5-year survival rate remains poor, ranging between 15 and $35 \%$. Among patients who relapse after curative surgery, the $87 \%$ have locoregional recurrences [43].

These facts have prompted many studies addressing surgical issues, as well as exploring the role of adjuvant and neoadjuvant treatments, such as perioperative chemotherapy, which associate with a 5-year overall survival benefit of $13 \%$ for stage II or III operable gastric cancer patients [1]. Worldwide, despite the improvements, estimated cure rates for patients with stages IIIA and IIIB remain poor [23]. These data highlight the urgent need of new therapeutic strategies to combat gastric cancer, such as epithelial growth factor receptor (EGFR) inhibitors [49], anti-angiogenetic agents [46], apoptosis promoters [39] and specific immunotherapy [9].

The fight against gastric cancer has adopted several approaches to exploit the cancer-specific immune response [9], such as patient vaccination with dendritic cells pulsed with HER-2/neu-derived peptides [21] and vaccination by injection of peptides of tumor-associated antigens $[44,45]$. In various studies of gastric cancer immunotherapy, there were positive effects for only a few patients. The disparities registered in cancer immunotherapy trials might be due to a different degree or type of immune response to the tumor antigens in individual patients. The functional properties of the gastric cancer antigen-specific $T$ cells have not yet fully elucidated.

The aim of this study was to characterize the effector functions of the gastric cancer-associated antigen (GCAA) peptide-specific T cells, isolated from either the gastric cancer tissue or the peripheral blood of patients with gastric adenocarcinoma.

\section{Materials and methods}

Patients

Twenty patients (mean age 68 years) were enrolled in the study. Fully informed consent and approval of the local Ethical Committee were obtained. The characteristics of the patients are summarized in Table 1. Patients were selected on the basis of their HLA-A02 and/or HLA-A24 alleles. In all patients the diagnosis of gastric adenocarcinoma was confirmed at pathology: 8 cases had the diffuse type cancer, and 12 had the intestinal type. Patients underwent surgical resection of the primary lesion and did not receive chemotherapy. Gastric biopsies were obtained by endoscopy from 15 patients with chronic gastritis (mean age 65 years) and HLA-A02 and/or HLA-A24 alleles (disease controls). Patients with the evidence of serious illness, immunosuppression, autoimmune or infectious diseases were excluded.

\section{Reagents}

Recombinant human IL-2 was a kind gift from Eurocetus (Milan, Italy). PHA (M form) was purchased from Gibco Laboratories (Grand Island, USA), ionomycin and phorbol 12-myristate 13-acetate (PMA) from Sigma (St. Louis, USA). Anti-CD3, anti-CD4, anti-CD8, anti-IFN- $\gamma$, anti-IL-4, anti-CD28 and anti-CD49d monoclonal antibodies (mAbs) were purchased from BD Biosciences (San Jose, USA); the mAbs anti-HLA-DR and anti-HLA-A-B-C were purchased from Immunotech (Beckman Coulter, Marseille, France). The peptides of gastric cancer-associated antigens (GCAA) used in the present study were prepared by Multiple Peptide System (San Diego, USA). The sequences of the GCAA peptides are reported in Table 2 . All these peptides have proven the ability to induce HLA-A02- or HLA-A24restricted and tumor-specific cytotoxic lymphocyte activity in the PBMCs of gastric cancer patients [27, 47, 51].

Generation of $\mathrm{T}$ cell clones from TILs of the neoplastic gastric tissue

Surgical specimens of gastric cancer tissue or endoscopic biopsy samples from the gastric mucosa of control patients with chronic gastritis were cultured for 7 days in RPMI 1640 medium supplemented with IL-2 $(50 \mathrm{U} / \mathrm{ml})$ in order to expand in vivo-activated TILs. Specimens were then disrupted, and single $\mathrm{T}$ cell blast was cloned under limiting dilution, as described [4]. Briefly, single $\mathrm{T}$ cell blasts were seeded in microwells $(0.3$ cells/well $)$ in the presence of $2 \times 10^{5}$ irradiated (5,000 rad) PBMC, PHA (0.5\% vol/ $/ \mathrm{vol})$, and IL-2 (50 U/ml). At weekly intervals, $2 \times 10^{5}$ irradiated PBMC and IL-2 were added to each microculture to maintain the expansion 
Table 1 HLA-A allele, gastric pathology and GCAA peptide reactivity of $\mathrm{T}$ cell clones generated from TILs isolated from the neoplastic tissue of gastric adenocarcinoma (GA) patients or from gastric mucosainfiltrating $\mathrm{T}$ cells of patients with chronic gastritis (CG)

GA gastric adenocarcinoma

\begin{tabular}{|c|c|c|c|c|c|}
\hline \multirow[t]{2}{*}{ Code } & \multirow[t]{2}{*}{ Sex/age } & \multirow[t]{2}{*}{ HLA-A allele } & \multirow[t]{2}{*}{ Gastric pathology } & \multicolumn{2}{|c|}{ No. of clones obtained } \\
\hline & & & & $\mathrm{CD}^{+}$ & $\mathrm{CD}^{+}$ \\
\hline \multicolumn{6}{|c|}{ No. of peptide-reactive clones } \\
\hline 01.BB & $72 \mathrm{M}$ & $\mathrm{A} 02-\mathrm{A} 24$ & Diffuse type GA & $0 / 15$ & $0 / 10$ \\
\hline 02.CC & $66 \mathrm{M}$ & A02-A24 & Diffuse type GA & $4 / 26$ & $4 / 18$ \\
\hline 03.CA & $63 \mathrm{~F}$ & $\mathrm{~A} 02$ & Diffuse type GA & $4 / 23$ & $2 / 18$ \\
\hline 04.FM & $66 \mathrm{M}$ & $\mathrm{A} 02$ & Diffuse type GA & $4 / 23$ & $3 / 19$ \\
\hline 05.PF & $63 \mathrm{M}$ & A24 & Diffuse type GA & $5 / 26$ & $4 / 15$ \\
\hline 06.Can & $65 \mathrm{~F}$ & A24 & Diffuse type GA & $2 / 20$ & $3 / 12$ \\
\hline 07.CS & $68 \mathrm{M}$ & A24 & Diffuse type GA & $0 / 18$ & $0 / 11$ \\
\hline 08.DN & $65 \mathrm{~F}$ & A24 & Diffuse type GA & $4 / 25$ & $4 / 15$ \\
\hline 09.BG & $74 \mathrm{M}$ & A02-A24 & Intestinal type GA & $3 / 27$ & $4 / 19$ \\
\hline 10.BA & $74 \mathrm{M}$ & A02-A24 & Intestinal type GA & $3 / 21$ & $4 / 17$ \\
\hline 11.BS & $63 \mathrm{M}$ & A02-A24 & Intestinal type GA & $4 / 24$ & $3 / 14$ \\
\hline 12.BGi & $62 \mathrm{M}$ & $\mathrm{A} 02$ & Intestinal type GA & $4 / 22$ & $4 / 18$ \\
\hline 13.MS & $64 \mathrm{~F}$ & A02 & Intestinal type GA & $3 / 18$ & $3 / 14$ \\
\hline 14. AC & $62 \mathrm{M}$ & A02 & Intestinal type GA & $4 / 22$ & $4 / 15$ \\
\hline 15.PM & $64 \mathrm{~F}$ & A02 & Intestinal type GA & $4 / 24$ & $3 / 20$ \\
\hline 16.MG & $79 \mathrm{~F}$ & A02 & Intestinal type GA & $0 / 16$ & $0 / 11$ \\
\hline 17.MM & $65 \mathrm{~F}$ & $\mathrm{~A} 02$ & Intestinal type GA & $4 / 23$ & $3 / 12$ \\
\hline 18.SB & $71 \mathrm{~F}$ & A24 & Intestinal type GA & $4 / 21$ & $5 / 17$ \\
\hline 19.AB & $77 \mathrm{M}$ & A24 & Intestinal type GA & $5 / 23$ & $3 / 20$ \\
\hline $20 . \mathrm{BF}$ & $60 \mathrm{M}$ & A24 & Intestinal type GA & $4 / 22$ & $3 / 21$ \\
\hline All GA patients & & & & $65 / 437$ & $59 / 316$ \\
\hline 21.GG & $71 \mathrm{M}$ & A02-A24 & Chronic gastritis & $0 / 17$ & $0 / 7$ \\
\hline 22.CJ & $74 \mathrm{~F}$ & A02-A24 & Chronic gastritis & $0 / 15$ & $0 / 6$ \\
\hline 23.BU & $71 \mathrm{M}$ & A02-A24 & Chronic gastritis & $0 / 22$ & $0 / 8$ \\
\hline 24.LL & $61 \mathrm{~F}$ & $\mathrm{~A} 02$ & Chronic gastritis & $0 / 25$ & $0 / 10$ \\
\hline 25.AG & $65 \mathrm{M}$ & $\mathrm{A} 02$ & Chronic gastritis & $0 / 18$ & $0 / 8$ \\
\hline 26.TS & $65 \mathrm{~F}$ & $\mathrm{~A} 02$ & Chronic gastritis & $0 / 22$ & $0 / 11$ \\
\hline 27.VA & $62 \mathrm{~F}$ & $\mathrm{~A} 02$ & Chronic gastritis & $0 / 14$ & $0 / 8$ \\
\hline $28 . \mathrm{TF}$ & $62 \mathrm{M}$ & $\mathrm{A} 02$ & Chronic gastritis & $0 / 17$ & $0 / 8$ \\
\hline 29.CZ & $62 \mathrm{~F}$ & $\mathrm{~A} 02$ & Chronic gastritis & $0 / 15$ & $0 / 6$ \\
\hline 30.PL & $59 \mathrm{M}$ & A24 & Chronic gastritis & $0 / 22$ & $0 / 11$ \\
\hline 31.SF & $75 \mathrm{M}$ & A24 & Chronic gastritis & $0 / 20$ & $0 / 9$ \\
\hline $32 . \mathrm{ZF}$ & $64 \mathrm{M}$ & A24 & Chronic gastritis & $0 / 19$ & $0 / 7$ \\
\hline $33 . \mathrm{VV}$ & $64 \mathrm{M}$ & A24 & Chronic gastritis & $0 / 19$ & $0 / 9$ \\
\hline 34.LS & $63 \mathrm{M}$ & A24 & Chronic gastritis & $0 / 21$ & $0 / 8$ \\
\hline 35.PO & $62 \mathrm{~F}$ & A24 & Chronic gastritis & $0 / 16$ & $0 / 4$ \\
\hline All CG patients & & & & $0 / 282$ & $0 / 120$ \\
\hline
\end{tabular}

of growing clones. $\mathrm{T}$ cell clones were screened for responsiveness to GCAA peptides by measuring $\left[{ }^{3} \mathrm{H}\right]$ thymidine (Amersham Pharmacia Biotech, Uppsala, Sweden) uptake after 60 -h co-culture with irradiated autologous mononuclear cells in the presence of medium or GCAA peptides $(10 \mu \mathrm{g} / \mathrm{ml})$. The mitogenic index (MI) was calculated as the ratio between mean values of cpm obtained in stimulated cultures and those obtained in the presence of medium alone. A MI $\geq 5$ was considered as positive.

Analysis of TCR VB chain repertoire of GCAA peptide-specific $\mathrm{T}$ cell clones

The repertoire of the TCR VB chain of GCAA peptide-specific $\mathrm{T}$ cell clones was analyzed with a panel of $24 \mathrm{mAbs}$ 
Table 2 Tumor associated antigens and peptide sequences

\begin{tabular}{|c|c|c|}
\hline \multirow[t]{2}{*}{ Antigen [Ref.] } & \multicolumn{2}{|c|}{ Peptide sequence and HLA restriction } \\
\hline & HLA-A24 & HLA-A02 \\
\hline SART1 [47] & SART1-690 (EYRGFTQDF) & \\
\hline SART2 [34] & $\begin{array}{l}\text { SART2-93 (DYSARWNEI) } \\
\text { SART2-161 (AYDFLYNYL) } \\
\text { SART2-899 (SYTRLFLIL) }\end{array}$ & \\
\hline SART3 [51] & $\begin{array}{l}\text { SART3-109 (VYDYNCHVDL) } \\
\text { SART3-315 (AYIDFEMKI) }\end{array}$ & $\begin{array}{l}\text { SART3-302 (LLQAEAPRL) } \\
\text { SART3-309 (RLAEYQAYI) }\end{array}$ \\
\hline СурВ [13] & $\begin{array}{l}\text { CypB-84 (KFHRVIKDF) } \\
\text { CypB-91 (DFMIQGGDF) }\end{array}$ & $\begin{array}{l}\text { CypB-129 (KLKHYGPGWV) } \\
\text { CypB-172 (VLEGMEVV) }\end{array}$ \\
\hline lck [16] & $\begin{array}{l}\text { lck-208 (HYTNASDGL) } \\
\text { lck-486 (TFDYLRSVL) } \\
\text { lck-488 (DYLRSVLEDF) }\end{array}$ & $\begin{array}{l}\text { lck-246 (KLVERLGAA) } \\
\text { lck-422 (DVWSFGILL) }\end{array}$ \\
\hline ART-1 [38] & ART1-170 (EYCLKFTKL) & \\
\hline ART-4 [19] & $\begin{array}{l}\text { ART4-13 (AFLRHAAL) } \\
\text { ART4-75 (DYPSLSATDI) }\end{array}$ & \\
\hline EIF-4EBP [45] & & EIF-4EBP-51 (RIIYDRKFL) \\
\hline ppMAPkkk [17] & & $\begin{array}{l}\text { ppMAPkkk-294 (GLLFLHTRT) } \\
\text { ppMAPkkk-432 (DLLSHAFFA) }\end{array}$ \\
\hline WHSC2 [27] & & $\begin{array}{l}\text { WHSC2-103 (ASLDSDPWV) } \\
\text { WHSC2-141 (ILGELREKV) }\end{array}$ \\
\hline UBE2V [17] & & $\begin{array}{l}\text { UBE2V-43 (RLQEWCSVI) } \\
\text { UBE2V-85 (LIADFLSGL) } \\
\text { UBE2V-208 (ILPRKHHRI) }\end{array}$ \\
\hline HNRPL [17] & & $\begin{array}{l}\text { HNRPL-140 (ALVEFEDVL) } \\
\text { HNRPL-501 (NVLHFFNAPL) }\end{array}$ \\
\hline
\end{tabular}

SART squamous cell carcinoma antigen recognized by $\mathrm{T}$ cells, CypB cyclophilin B,

lck leukocyte-specific protein tyrosine kinase, ART adenocarcinoma antigen recognized by T cells, EIF-4EBP eukaryotic translation Initiation factor-4E binding protein, $p p M A P k k k$ partial putative mitogenactivated protein kinase kinase kinase, WHSC2 WolfHirschhorn syndrome candidate 2 protein, $U B E 2 V$ ubiquitinconjugating enzyme variant kua, HNRPL heterogeneous nuclear ribonucleoprotein $\mathrm{L}$
Cytofluorimetric analysis of $\mathrm{T}$ cell surface markers and characterization of the cytokine profile of GCAA peptide-specific $\mathrm{T}$ cell clones

Cell surface marker analysis of $\mathrm{T}$ cells was carried out by two- or three-color flow cytometry using fluorochromeconjugated anti-CD3, anti-CD4, anti-CD8. The cells were analyzed on a BD FACScan cytofluorimeter using the Diva software (BD Biosciences, San Jose, USA). A total of $10^{4}$ events for each sample were acquired.

To induce the cytokine production by GCAA peptidespecific $\mathrm{T}$ cell clones, $10^{6} \mathrm{~T}$ cell blasts of each clone were co-cultured for $48 \mathrm{~h}$ in $1 \mathrm{ml}$ medium with $5 \times 10^{5}$ irradiated autologous PBMCs as antigen presentig cells (APC) with or without single GCAA peptides $(10 \mu \mathrm{g} / \mathrm{ml})$.

To elicit cytokine production by non-GCAA-specific $\mathrm{T}$ cell clones, $\mathrm{T}$ cell blasts were resuspended at $10^{6} / \mathrm{ml}$ medium and cultured for $36 \mathrm{~h}$ in the presence of PMA (10 ng/ml) plus ionomycin $(200 \mathrm{ng} / \mathrm{ml})$. Cell-free supernatants were collected and assayed in duplicate for IFN- $\gamma$ and IL-4 content by commercial ELISA assays (Bio-Source International, Camarillo). Supernatants showing IFN- $\gamma$ or 
IL-4 levels 5 SD over the mean levels in control supernatants derived from irradiated APC alone were regarded as positive. $\mathrm{CD}^{+}$and $\mathrm{CD}^{+} \mathrm{T}$ cell clones able to produce IFN- $\gamma$, but not IL-4, were categorized as Th1 or Tc1, respectively, whereas clones able to produce both IL-4 and IFN- $\gamma$, as Th0 or Tc 0 , respectively.

Preparation of Epstein-Barr virus transformed (EBV-B) cells

B cell-enriched suspensions were prepared by a double-step rosetting with neuraminidase-treated sheep erythrocytes, as described elsewhere [6]. Peripheral blood B cell-enriched suspensions usually consisted of $68-87 \%$ B cells, 9-21\% monocytes, and $\leq 1 \% \mathrm{~T}$ cells. They will be referred to as $\mathrm{B}$ cells. To obtain EBV-transformed lymphoblastoid B cell lines, B cells were incubated for $48 \mathrm{~h}$ with supernatant of the EBV-producing marmoset cell line B95.8 and subsequently expanded in complete medium supplemented with $15 \%$ FCS.

Perforin-mediated cytotoxicity and Fas-Fas

Ligand(L)-mediated proapoptotic activity

Perforin-mediated cytolytic activity of $\mathrm{T}$ cell clones was assessed as reported [5]. T cell blasts of GCAA peptide-specific clones were incubated at effector to target ratios of 10,5 , and 2.5-1 with ${ }^{51} \mathrm{Cr}$-labeled autologous EBV-B cells preincubated with peptide $(10 \mu \mathrm{g} / \mathrm{ml})$. After centrifugation, microplates were incubated for $8 \mathrm{~h}$ at $37^{\circ} \mathrm{C}$, and $0.1 \mathrm{ml}$ supernatant was removed from each microculture for measurement of ${ }^{51} \mathrm{Cr}$ release. The ability of GCAA peptide-specific $\mathrm{T}$ cell clones to induce Fas-FasL-mediated apoptosis was assessed using $\mathrm{Fas}^{+}$Jurkat cells as target [50]. T cell blasts from each clone were co-cultured with ${ }^{51} \mathrm{Cr}$-labeled Jurkat cells at effector to target ratios of 10,5 , and $2.5-1$ for $18 \mathrm{~h}$ in the presence of PMA (10 ng/ml) and ionomycin $(1 \mathrm{mmol} / \mathrm{l})$, as reported [4]. To block Fas-FasL interaction, the anti-Fas antagonistic monoclonal antibody M3 (Amgen, Thousand Oaks, USA) was used at a $5 \mu \mathrm{g} / \mathrm{ml}$ final concentration in a 30-min pretreatment of ${ }^{51} \mathrm{Cr}$-labeled Jurkat cells, as reported [3].

Generation of GCAA peptide-specific T cell lines

Peptide-specific $\mathrm{T}$ cell lines were generated as described [7]. Briefly, $10^{6}$ PBMC in $2 \mathrm{ml}$ RPMI 1640 medium supplemented with $2 \mathrm{mM}$ L-glutamine, $2 \times 10^{-5} \mathrm{M} 2-\mathrm{ME}$, and $5 \%$ human serum (complete medium) were stimulated with single GCAA peptides $(10 \mu \mathrm{g} / \mathrm{ml})$ in 24 -well flat-bottom plates for 5 days. Human IL-2 $(30 \mathrm{U} / \mathrm{ml})$ was then added, and cultures were continued for 7 days. Viable $\mathrm{T}$ cell blasts were resuspended in complete medium and tested for their intracytoplasmatic cytokine expression.
Cytofluorometric analysis of the intracytoplasmic cytokine production of the GCAA peptide-specific $\mathrm{T}$ cell lines

Cytofluorometric analysis of intracytoplasmic IFN- $\gamma$ and IL-4 synthesis in GCAA peptide-specific T cell lines was performed after 10 days of culture. Briefly, after washing with PBS, $1 \times 10^{6} \mathrm{~T}$ cell blasts were stimulated with single peptides $(10 \mu \mathrm{g} / \mathrm{ml})$ plus anti-human CD28 $(1 \mu \mathrm{g} / \mathrm{ml})$ and anti-human CD49d $(1 \mu \mathrm{g} / \mathrm{ml})$ for $6 \mathrm{~h}$, being the last two mAbs added in the presence of brefeldin A $(5 \mu \mathrm{g} / \mathrm{ml})$. After incubation, cells were washed twice with PBS, $\mathrm{pH}$ 7.2, fixed 15 min with formaldehyde (2\% in PBS, $\mathrm{pH} 7.2$ ), washed twice with $0.5 \%$ BSA in PBS, pH 7.2, permeabilized with PBS, pH 7.2, containing 0.5\% BSA and 0.5\% saponin, and then incubated with the specific mAbs. Cells were analyzed on a FACScan cytofluorometer using the Diva software. The area of positivity was determined using an isotype-matched $\mathrm{mAb}$. In all cytofluorometric analysis, a total of $10^{4}$ events, gated as $\mathrm{CD}^{+} \mathrm{CD}^{+}$or $\mathrm{CD}^{+} \mathrm{CD}^{+}$ cells, for each sample, were acquired.

\section{Results}

GCAA peptide-specific T cells infiltrate the neoplastic tissue of patients with gastric adenocarcinoma

$\mathrm{T}$ cell clones derived from the TILs of gastric cancer patients were assayed for proliferation in response to each of the GCAA peptides reported in Table 2. Among the 437 $\mathrm{CD}^{+}{ }^{+}$TIL-derived $\mathrm{T}$ cell clones, 65 (15\%) (Table 1) proliferated to different GCAA peptides. Of the 65 peptide-specific $\mathrm{CD} 4^{+} \mathrm{T}$ cell clones, 30 were activated by peptides restricted by HLA-A24, whereas the other 35 recognized their target peptide in the context of HLA-A02 (Table 1; Fig. 1). Among the $316 \mathrm{CD} 8^{+} \mathrm{T}$ cell clones generated from the TILs of gastric cancer (Table 1), 59 (18\%) proliferated to GCAA peptides: namely, $29 \mathrm{CD} 8^{+}$clones responded to peptides restricted by HLA-A24 and 30 to peptides restricted by HLA-A02 (Table 1; Fig. 1). Under the same experimental conditions, none of the $282 \mathrm{CD}^{+}$and none of the $120 \mathrm{CD}^{+} \mathrm{T}$ cell clones obtained from endoscopic biopsies of the gastric mucosa of patients with chronic gastritis showed significant proliferation to any GCAA peptide (Table 1). As shown in Fig. 1, in the series of TIL-derived clones, we found $\mathrm{CD}^{+}$and/or $\mathrm{CD} 8^{+}$clones reactive to one or more peptides of the panel of GCAA peptides used in this study (Table 3), those of antigens SART and lck having higher chance to be recognized by the clonal progenies of TILs from our patients. However, in three patients (1.BB, 7.CS, and 16.MG) (15\%) we were unable to isolate any $\mathrm{T}$ cell clone specific for any of the GCAA peptides used in this study. Evidence for clonality of GCAA peptide-specific 
Mitogenic Index

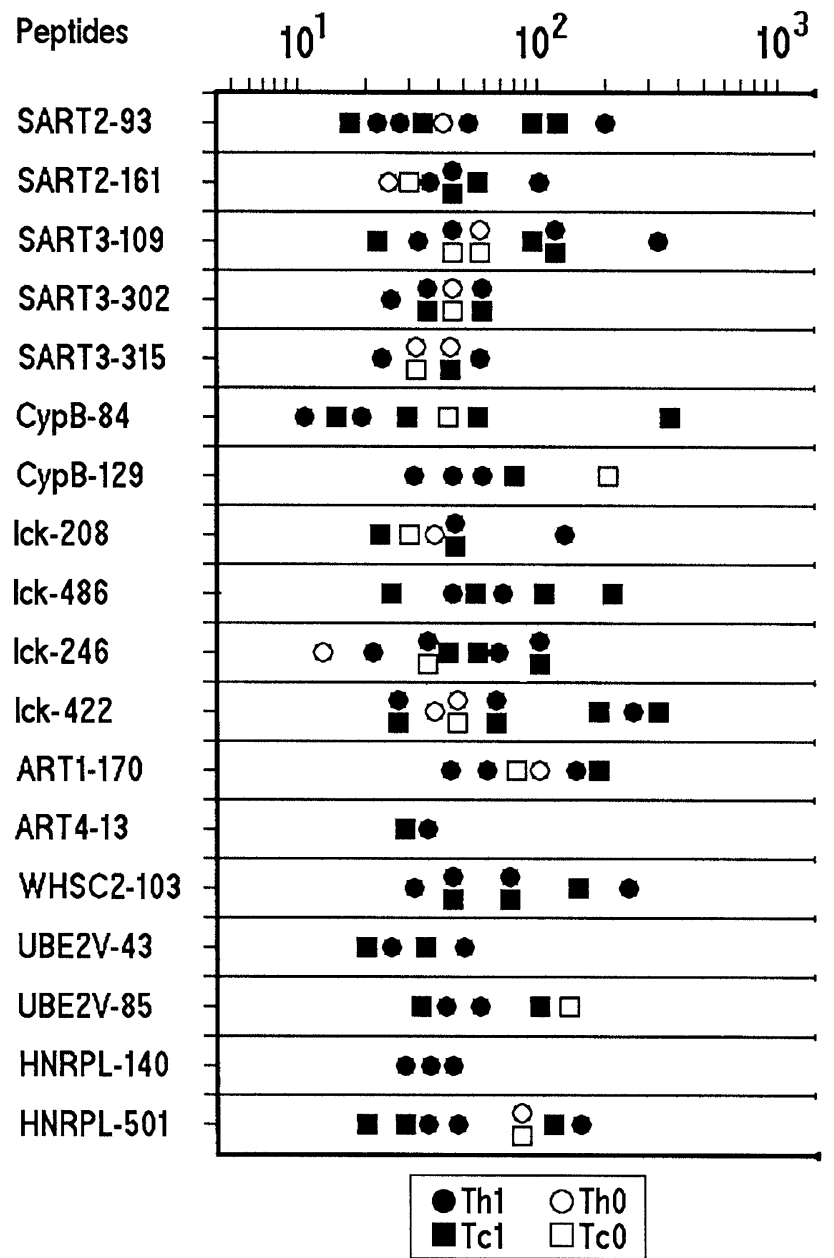

Fig. 1 Repertoire of TIL-derived T cell clones reactive to peptides obtained from gastric cancer-associated antigens. Th1 and Th0 CD4 ${ }^{+}$ clones (closed and open circles, respectively) and Tc1 and Tc0 $\mathrm{CD} 8^{+}$ clones (closed and open squares, respectively) were tested for proliferation to GCAA peptides in the presence of irradiated autologous APCs. Results are expressed as mean values of mitogenic index obtained in triplicate microcultures

$\mathrm{T}$ cell clones was provided by the cytofluorimetric patterns of single TCR-VB expression shown by those clones. Each $\mathrm{T}$ cell clone was stained by only one of the TCR-VB chainspecific monoclonal antibodies, showing a single peak of fluorescence intensity (Fig. 2).

To assess whether the responses of $\mathrm{CD}^{+} \mathrm{T}$ cell clones were HLA class I- or class II-restricted, cell proliferation tests with GCAA peptides were performed in the presence of autologous mononuclear cells and anti-HLA class I or anti-HLA class II blocking mAbs $(10 \mu \mathrm{g} / \mathrm{ml})$. On the basis of the results obtained (Table 4 ), it is possible to conclude that some TIL-derived $\mathrm{CD} 4^{+} \mathrm{T}$ cell clones ( 38 of $65,58 \%$ ) showed an HLA class I-restricted response to GCAA peptides, whereas the response of the rest of $\mathrm{CD} 4^{+}$clones (27 of $65,42 \%$ ) was HLA class II-restricted. The number of
Table 3 Cancer antigen peptide specificity of $\mathrm{T}$ cell clones generated from TILs isolated from neoplastic tissue of gastric adenocarcinoma patients

\begin{tabular}{|c|c|c|c|c|}
\hline \multirow{3}{*}{$\begin{array}{l}\text { Patients } \\
\text { 02.CC }\end{array}$} & \multicolumn{4}{|c|}{$\begin{array}{l}\text { Peptide-specificity of TIL-derived T cell clones in single } \\
\text { patients }\end{array}$} \\
\hline & \multicolumn{2}{|c|}{$\begin{array}{l}\text { Number of reactive } \\
\mathrm{CD} 4^{+} \text {clones }\end{array}$} & \multicolumn{2}{|c|}{$\begin{array}{l}\text { Number of reactive } \\
\mathrm{CD} 8^{+} \text {clones }\end{array}$} \\
\hline & 2 & SART3-315 & 2 & SART2-93 \\
\hline & 1 & SART3-309 & 1 & СурВ-172 \\
\hline & 1 & lck-246 & 1 & UBE2V-85 \\
\hline \multirow[t]{2}{*}{ 03.CA } & 3 & lck-422 & 1 & UBE2V-208 \\
\hline & 1 & UBE2V-43 & 1 & СурВ-172 \\
\hline \multirow[t]{2}{*}{ 04.FM } & 3 & СурB-172 & 2 & lck-422 \\
\hline & 1 & SART3-309 & 1 & SART3-302 \\
\hline \multirow[t]{3}{*}{ 05.PF } & 2 & SART2-93 & 2 & lck-486 \\
\hline & 2 & lck-208 & 1 & lck-208 \\
\hline & 1 & lck-488 & 1 & SART2-93 \\
\hline \multirow[t]{2}{*}{ 06.CAn } & 2 & СурB-84 & 2 & СурB-84 \\
\hline & & & 1 & ART4-13 \\
\hline \multirow[t]{2}{*}{ 08.DN } & 2 & lck-208 & 3 & SART3-109 \\
\hline & 2 & SART3-109 & 1 & СурB-84 \\
\hline \multirow[t]{2}{*}{ 09.BG } & 2 & lck-246 & 2 & lck-246 \\
\hline & 1 & ART4-13 & 2 & lck-486 \\
\hline \multirow[t]{2}{*}{ 10.BA } & 2 & SART2-93 & 2 & SART3-109 \\
\hline & 1 & HNRPL-140 & 2 & HNRPL-501 \\
\hline \multirow[t]{3}{*}{ 11.BS } & 2 & SART2-161 & 1 & SART2-161 \\
\hline & 2 & HNRPL-140 & 1 & SART3-315 \\
\hline & & & 1 & СурB-84 \\
\hline \multirow[t]{3}{*}{ 12.BG } & 2 & lck-422 & 2 & SART3-302 \\
\hline & 1 & SART3-302 & 2 & UBE2V-85 \\
\hline & 1 & UBE2V-85 & & \\
\hline \multirow[t]{2}{*}{ 13.MS } & 2 & SART3-302 & 3 & WHSC2-103 \\
\hline & 1 & WHSC2-103 & & \\
\hline \multirow[t]{3}{*}{ 14. AC } & 2 & HNRPL-501 & 2 & lck-422 \\
\hline & 1 & UBE2V-43 & 2 & UBE2V-43 \\
\hline & 1 & UBE2V-85 & & \\
\hline \multirow[t]{2}{*}{ 15.PM } & 2 & SART3-302 & 1 & SART3-302 \\
\hline & 2 & lck-246 & 2 & lck-246 \\
\hline \multirow[t]{2}{*}{ 17.MM } & 2 & WHSC2-103 & 1 & lck-422 \\
\hline & 2 & HNRPL-501 & 2 & HNRPL-501 \\
\hline \multirow[t]{3}{*}{ 18.SB } & 2 & SART3-315 & 2 & SART2-161 \\
\hline & 2 & ART4-75 & 2 & ART1-170 \\
\hline & & & 1 & lck-208 \\
\hline \multirow[t]{3}{*}{ 19.AB } & 2 & SART2-161 & 1 & SART2-93 \\
\hline & 2 & ART4-75 & 1 & SART3-315 \\
\hline & 1 & lck-488 & 1 & lck-208 \\
\hline \multirow[t]{2}{*}{ 20.BF } & 3 & SART3-309 & 2 & SART3-109 \\
\hline & 1 & SART2-93 & 1 & СурВ-84 \\
\hline
\end{tabular}

peptide-specific $\mathrm{CD} 4^{+} \mathrm{T}$ cell clones that exhibited proliferation in a MHC class I manner is very restricted (one or two per patient). 
Fig. 2 TCR Vß chain collection of GCAA peptides-specific $\mathrm{T}$ cell clones. The clonality of $\mathrm{T}$ cell clones reactive tumoral antigen peptides was analyzed by a panel of 24 monoclonal antibodies specific for human TCR Vß chain families, as detailed in "Materials and methods". T cell blasts from each clone were divided in aliquots and stained with each of the monoclonal antibody and the appropriate isotype controls
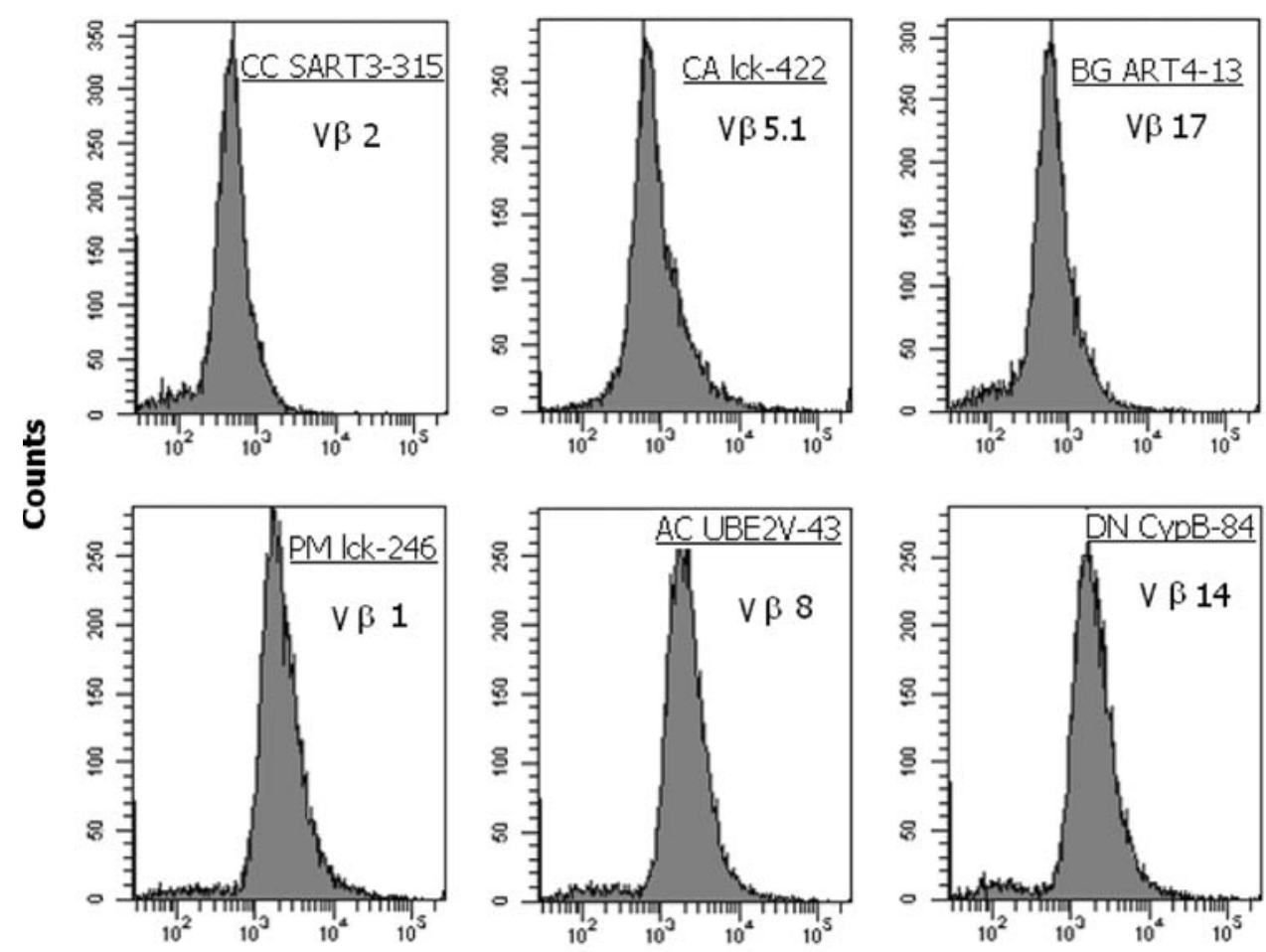

Fluorescence Intensity
Table 4 Effect of anti-HLA class I and II monoclonal antibodies on $\mathrm{T}$ cell clone proliferation induced by GCAA peptides
$M I$ mitogenic index, $S D$ standard deviation

\begin{tabular}{|c|c|c|c|}
\hline $\begin{array}{l}\text { Phenotype of clones/ } \\
\text { specific peptides }\end{array}$ & $\begin{array}{l}\text { Peptide } \\
\text { alone }(\mathrm{MI} \pm \mathrm{SD})\end{array}$ & $\begin{array}{l}\text { Peptide }+ \text { anti-HLA } \\
\text { class I (\% inhibition) }\end{array}$ & $\begin{array}{l}\text { Peptide + anti-HLA } \\
\text { class II (\% inhibition) }\end{array}$ \\
\hline \multicolumn{4}{|l|}{ Culture conditions } \\
\hline $\mathrm{CD}^{+} / \mathrm{SART} 2-93$ & $51.7 \pm 5.2$ & $8.2 \pm 1.2(84)$ & $42.5 \pm 3.2(18)$ \\
\hline $\mathrm{CD}^{+} / \mathrm{lck}-208$ & $63.4 \pm 4.1$ & $7.7 \pm 3.1(88)$ & $54.3 \pm 5.4(14)$ \\
\hline $\mathrm{CD}^{+} / \mathrm{lck}-488$ & $72.6 \pm 3.4$ & $56.6 \pm 7.4(12)$ & $13.7 \pm 2.2(81)$ \\
\hline $\mathrm{CD}^{+} / \mathrm{ART} 4-13$ & $52.3 \pm 3.7$ & $14.2 \pm 2.3(73)$ & $41.1 \pm 9.1(21)$ \\
\hline $\mathrm{CD}^{+} / \mathrm{HNRPL}-501$ & $57.2 \pm 8.5$ & $49.7 \pm 5.2(13)$ & $11.2 \pm 1.5(80)$ \\
\hline $\mathrm{CD} 4^{+} / \mathrm{UBE} 2 \mathrm{~V}-43$ & $62.3 \pm 2.5$ & $12.4 \pm 4.3(80)$ & $47.7 \pm 8.7(13)$ \\
\hline $\mathrm{CD}^{+} / \mathrm{SART} 2-93$ & $35.3 \pm 5.3$ & $4.7 \pm 1.2(87)$ & $27.1 \pm 6.3(13)$ \\
\hline $\mathrm{CD}^{+} / \mathrm{lck}-208$ & $42.5 \pm 6.1$ & $5.2 \pm 0.8(88)$ & $37.4 \pm 7.2(12)$ \\
\hline $\mathrm{CD}^{+} / \mathrm{lck}-486$ & $26.7 \pm 4.3$ & $4.5 \pm 3.2(83)$ & $21.5 \pm 6.1(19)$ \\
\hline $\mathrm{CD}^{+} / \mathrm{CypB}-172$ & $33.5 \pm 3.8$ & $8.3 \pm 1.2(75)$ & $29.5 \pm 4.8(12)$ \\
\hline $\mathrm{CD}^{+} /$WHSC2-103 & $56.4 \pm 5.1$ & $11.6 \pm 5.2(79)$ & $48.7 \pm 5.7(14)$ \\
\hline CD $8{ }^{+} / \mathrm{HNRPL}-501$ & $47.3 \pm 5.6$ & $6.7 \pm 1.1(76)$ & $38.9 \pm 3.9(18)$ \\
\hline
\end{tabular}

As expected, all the $\mathrm{CD} 8^{+}$GCAA peptide-specific $\mathrm{T}$ cell clones showed an HLA class I-restricted response.

Th1/Tc1 effector functions of TIL-derived T cell clones specific for GCAA peptides

The cytokine profile induced in peptide-specific TILderived $\mathrm{T}$ cell clones by stimulation with the appropriate GCAA peptide in the presence of irradiated autologous APC was then assessed. Upon stimulation with the specific peptide, the majority of peptide-reactive $\mathrm{CD} 4^{+}$and/or $\mathrm{CD} 8^{+}$ clones produced IFN- $\gamma$, but not Th2 cytokines, expressing thus the Th1/Tc1 profile, whereas $17 \%$ of $\mathrm{CD}^{+}$and $25 \%$ of $\mathrm{CD} 8^{+}$clones expressed a $\mathrm{Th} 0$ or $\mathrm{Tc} 0$ profile, respectively, with production of both IFN- $\gamma$ and IL-4 (Fig. 3).

Since most of antigen-activated Th1 and Th0 clones express perforin-mediated cytotoxicity against autologous antigen-presenting APC (e.g., GCAA peptidepulsed $B$ cells) [3], we assessed the cytolytic potential of peptide-specific $\mathrm{T}$ cell clones using GCAA peptide-pulsed 


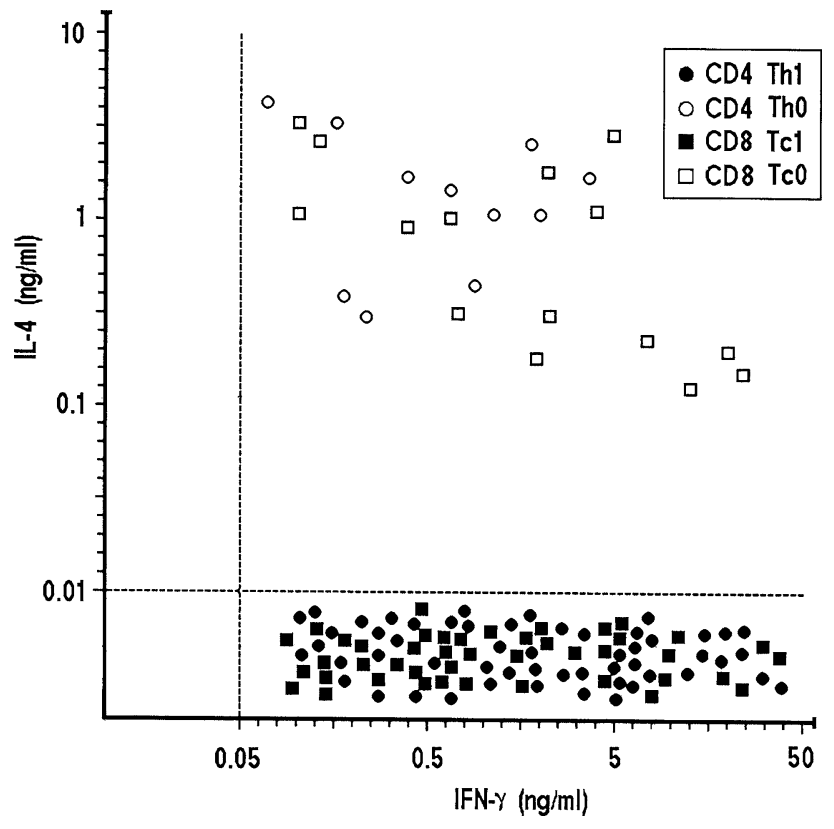

Fig. 3 Gastric cancer antigen peptide-induced cytokine production by TIL-derived T cell clones. GCAA peptide-specific Th1 and Th0 CD4 ${ }^{+}$ and $\mathrm{Tc} 1$ and $\mathrm{Tc} 0 \mathrm{CD}^{+} \mathrm{T}$ cell clones were stimulated with the appropriate peptides $(10 \mu \mathrm{g} / \mathrm{ml})$, and IFN- $\gamma$ and/or IL-4 production was measured in culture supernatants by specific ELISA assays. In supernatants of control cultures stimulated with medium alone, levels of IFN- $\gamma$ and IL-4 were consistently $<0.05$ and $<0.01 \mathrm{ng} / \mathrm{ml}$. Dotted lines represent 3 SD over the mean levels of IFN- $\gamma$ and IL- 4 measured in control cultures

${ }^{51} \mathrm{Cr}$-labeled autologous EBV-B cells as targets. At an effector to target ratio of $10: 1$, all $50 \mathrm{CD}^{+} \mathrm{Th} 1$ and 11 out of the $15 \mathrm{Th} 0 \mathrm{CD}^{+}$clones lysed GCAA peptide-presenting autologous EBV-B cells (Fig. 4). Likewise, all the $59 \mathrm{CD} 8^{+}$ (44 $\mathrm{Tc} 1$ and $15 \mathrm{Tc} 0$ ) $\mathrm{T}$ cell clones lysed GCAA peptidepresenting autologous EBV-B cells, at an effector to target ratio of 10:1 or lower.

Because activated effector $T$ cells can also kill their targets by inducing apoptosis through Fas-FasL interaction [50], the ability of activated peptide-specific $\mathrm{T}$ cell clones to induce ${ }^{51} \mathrm{Cr}$ release by $\mathrm{Fas}^{+}$Jurkat cells undergoing apoptosis was evaluated. Upon mitogen activation, 50 of 65 $\mathrm{CD}^{+}(77 \%)$ and $50(85 \%)$ out of $59 \mathrm{CD} 8^{+}$clones were able to induce apoptosis in target cells (Fig. 5). The role of FasFasL interaction in the ${ }^{51} \mathrm{Cr}$ release was confirmed by its inhibition (range 39.6-59.8\%) using a blocking anti-Fas antibody (data not shown).

GCAA peptide-specific T cells in the peripheral blood of patients with gastric cancer

In order to assess the presence of T cells specific for GCAA peptides in the peripheral blood of patients with gastric adenocarcinoma, PBMCs from all 20 patients were cultured $\left(3 \times 10^{5}\right)$ for 5 days in the presence of medium alone or

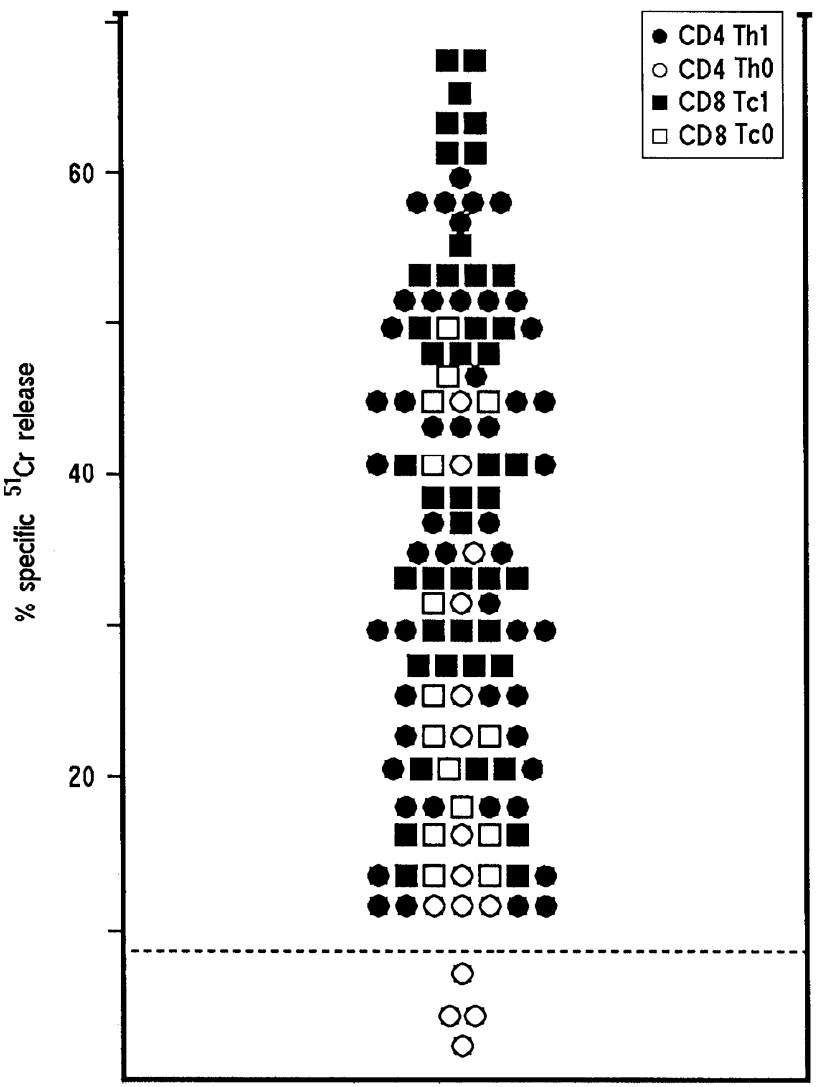

Fig. 4 Cancer antigen peptide-induced cytotoxicity of TIL-derived peptide-specific $\mathrm{CD}^{+}{ }^{+}$and $\mathrm{CD} 8^{+} \mathrm{T}$ cells clones. To assess their perforin-mediated cytotoxicity, $\mathrm{T}$ cell clones were cocultured with ${ }^{51} \mathrm{Cr}$-labeled autologous EBV-B cells pulsed with the appropriate GCAA peptides. Results represent mean values of percent specific ${ }^{51} \mathrm{Cr}$ release at an effector to target ratio of 10-1 in triplicate microcultures. The dotted line represents $3 \mathrm{SD}$ over the mean ${ }^{51} \mathrm{Cr}$ release in cultures with ${ }^{51} \mathrm{Cr}$-labeled autologous EBV-B cells pulsed with medium alone
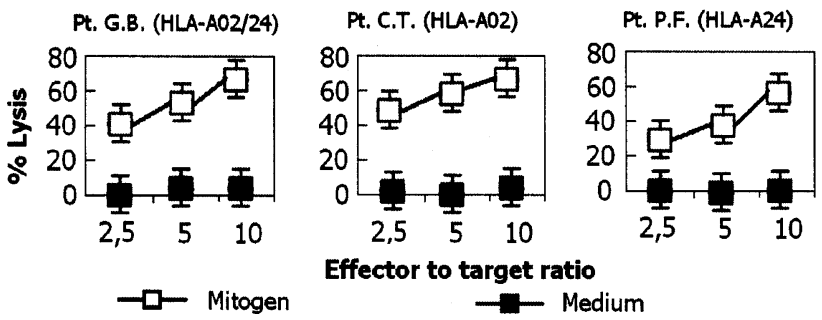

Fig. 5 Proapoptotic activity and cytotoxicity against gastric cancer cells lines. Proapoptotic activity of TIL-derived cancer peptide-specific $\mathrm{T}$ cell clones. To assess their ability to induce apoptosis in target cells, peptides-specific $\mathrm{T}$ cell clones were stimulated with mitogen (open squares) or medium alone (open squares) and cocultured with ${ }^{51} \mathrm{Cr}$-labeled Fas ${ }^{+}$Jurkat cells. ${ }^{51} \mathrm{Cr}$ release was then measured as index of apoptotic target cell death. Data of three representative clones are reported. Results represent mean values $( \pm \mathrm{SD})$

single GCAA peptides $(10 \mu \mathrm{g} / \mathrm{ml})$ of the series. The PBMCs of 14 patients $(70 \%)$ with gastric adenocarcinoma proliferated in the presence of GCAA peptides (data not shown). In particular, in four patients HLA-A02 $/ \mathrm{HLA}-\mathrm{A} 24^{+} \mathrm{PBMCs}$ 
proliferated to GCAA peptides restricted by one or the other HLA-A molecule, while in six patients HLA-A02 $/ \mathrm{HLA}-$ A24- proliferation occurred only upon stimulation with HLA-A02 restricted peptides and in the six patients HLAA02 ${ }^{-} / \mathrm{HLA}-\mathrm{A} 24^{+}$PBMCs recognized only HLA-A24 restricted GCAA peptides. The PBMCs from the remaining six patients with gastric adenocarcinoma or from the 15 chronic gastritis patients did not proliferate to any of the GCAA peptides tested.

Predominant Th1/Tc1 profile of GCAA peptide-specific $\mathrm{T}$ cell lines derived from PBMCs of patients with gastric cancer

Upon 5-day stimulation of patient PBMC with single GCAA peptides, peptide-specific $\mathrm{T}$ cell lines were expanded with IL-2 for additional 7 days. Peptide-specific $\mathrm{T}$ cell lines could be obtained from 16 out of the 20 patients studied, whereas no viable $\mathrm{T}$ cell line was derived from four of the six patients whose PBMCs did not proliferate to any of the tumor peptides. Incidentally, three of those four patients (1.BB, 7.CS and 16.MG) were the same in which we failed to derive and expand any tumor antigen-specific $\mathrm{T}$ cell clone. On day 10 , viable $\mathrm{T}$ cell blasts of the peptidespecific $\mathrm{T}$ cell lines were resuspended in complete medium and tested for their intracytoplasmatic cytokine expression. After stimulation with the appropriate HLA-A-restricted peptide in the presence of costimulatory molecules (antiCD28 and anti-CD49d), all T cell lines included a remarkable proportion of peptide-specific $\mathrm{CD}^{+}$and $\mathrm{CD}^{+} \mathrm{Th} 1$ (average 11\%) and Tc1 (average 15\%) cells able to produce intracytoplasmic IFN- $\gamma$, but only a few Th0 and Tc0 cells expressing both IFN- $\gamma$ and IL-4 (Table 5). In other words, the data from the peripheral blood confirmed the Th1/Tc1 predominance of the GCAA peptide-specific $\mathrm{T}$ cells derived from TILs of the gastric neoplastic tissues. It is interesting that in almost all patients the peptides that induced the production of IFN- $\gamma$ in PBMC were the same that stimulated the proliferation of the GCAA peptidespecific $\mathrm{T}$ cell clones isolated from the neoplastic tissues.

\section{Discussion}

In this study, the $\mathrm{T}$ cell response specific to gastric cancerassociated antigen (GCAA) peptides in 20 patients with gastric adenocarcinoma was analyzed. The use of a series of GCAA peptides allowed us to demonstrate the presence among the gastric tumor-infiltrating lymphocytes of $\mathrm{T}$ cells specific for GCAA peptides presented and restricted by HLA-A02 and/or HLA-A24 histocompatibility molecules. In view of the small number of TILs that can be recovered, the study took advantage of a high efficiency cloning proce-
Table 5 Intracytoplasmic cytokine synthesis by cancer antigen peptide-specific T cell lines generated from PBMC and stimulated with the relevant GCAA peptide

\begin{tabular}{lcccc}
\hline Patients & $\begin{array}{l}\text { Proportion }(\%) \text { of peptide-reactive T cell blasts expressing } \\
\text { cytokines }\end{array}$ \\
\cline { 2 - 5 } & $\mathrm{CD}^{+}{\mathrm{IFN}-\gamma^{+}}^{+}$ & $\mathrm{CD}^{+} \mathrm{IL}^{-} 4^{+}$ & $\mathrm{CD}^{+} \mathrm{IFN}^{-} \gamma^{+}$ & $\mathrm{CD}^{+} \mathrm{IL}^{+}{ }^{+}$ \\
\hline 02.CC & 11.2 & 0.11 & 15.1 & 0.19 \\
03.CA & 12.1 & $<0.1$ & 12.8 & $<0.1$ \\
04.FM & 6.2 & $<0.1$ & 10.3 & $<0.1$ \\
05.PF & 10.0 & 0.10 & 11.9 & 0.18 \\
06.CAn & 11.9 & $<0.1$ & 16.3 & 0.20 \\
08.DN & 10.9 & 0.20 & 13.9 & 0.10 \\
09.BG & 7.8 & $<0.1$ & 10.0 & $<0.1$ \\
10.BA & 10.3 & $<0.1$ & 13.0 & $<0.1$ \\
11.BS & 8.1 & $<0.1$ & 9.1 & $<0.1$ \\
12.BG & 8.9 & $<0.1$ & 10.8 & $<0.1$ \\
13.MS & 11.9 & 0.10 & 12.7 & 0.17 \\
14.AC & 7.0 & $<0.1$ & 10.1 & $<0.1$ \\
17.MM & 7.2 & $<0.1$ & 10.3 & 0.39 \\
18.SB & 11.8 & 0.19 & 15.0 & $<0.1$ \\
19.AB & 15.1 & 0.18 & 16.2 & $<0.1$ \\
20.BF & 10.1 & $<0.1$ & 11.4 & $<0.1$ \\
\hline
\end{tabular}

Intracytoplasmic IL- 4 and IFN- $\gamma$ positive $\mathrm{T}$ cell blasts of PBMCderived peptide-specific $\mathrm{T}$ cell lines. GCAA peptide specific $\mathrm{T}$ cell lines were obtained from 16 of 20 patients with gastric adenocarcinoma. T cell blasts were stimulated with peptides $(10 \mu \mathrm{g} / \mathrm{ml})$ and intracellular cytokine synthesis was evaluated by cytofluorometric analysis. Results represent mean proportions of cytokine-positive cells over the background values obtained with isotype-control monoclonal antibodies

dure allowing the clonal expansion of virtually every single $\mathrm{T}$ cell [30]. The analysis of the clonal progeny of TILs isolated from the neoplastic tissue showed a large predominancy of both $\mathrm{CD}^{+}$and $\mathrm{CD}^{+} \mathrm{T}$ cell clones able to secrete IFN- $\gamma$, whereas the concomitant production of IFN- $\gamma$ and IL-4 was limited to only a few clones. Therefore, the majority of gastric cancer TILs specific for GCAA peptides expressed the Th1 or Tc1 cytokine profile, whereas a much smaller proportion of GCAA peptide-specific TILs expressed the $\mathrm{Th} 0$ or Tc0 profile, according to their CD4 or CD8 phenotype, respectively.

A reasonable question is whether this pattern does indeed reflect the real functional behavior of gastric cancer TILs in vivo, or it is the result of in vitro artifacts due to culture in IL-2 and cloning procedure. In previous studies, however, using the very same culture and cloning protocol, $\mathrm{T}$ cell clones with predominant Th0 profile were obtained from the gastric mucosa of patients with chronic gastritis [2] and $\mathrm{T}$ cell clones polarized into the Th2 profile were obtained from the bronchial infiltrates of patients with allergic asthma [8].

Similar proportions of GCAA peptide-specific $\mathrm{T}$ cell clones were derived from $\mathrm{CD}^{+}(18 \%)$ and $\mathrm{CD}^{+}(15 \%)$ 
TILs isolated from the neoplastic lesions of gastric cancer patients. Classically, $\mathrm{CD} 4^{+} \mathrm{T}$ cells recognize antigens presented by MHC class II molecules, whereas $\mathrm{CD} 8^{+} \mathrm{T}$ cells recognize antigens presented by MHC class I molecules. However, there are several reported exceptions to this rule $[5,12,37,48]$. Accordingly, in our present studies we have found that a restricted number (one or two per patient) of specific $\mathrm{CD}^{+} \mathrm{T}$ cell clones showed an HLA class I-restricted response to GCAA peptides.

The series of peptide-specific TIL-derived T cell clones included clones with different specificity for HLA-A02 and/ or HLA-A24 restricted tumor antigen peptides. Although the repertoire of peptide specificity of TIL-derived $\mathrm{T}$ cell clones was wide (Table 3), including almost each of the different GCAA peptides tested, those specific for peptides belonging to SART3 and lck cancer antigens were the majority, being 24 and 32, respectively. For this aspect, our results are in agrement with the data of previous studies, which reported that the host immune response to gastric cancer frequently target SART and lck tumor-associatedantigens $[16,26,33,36]$.

The presence in the context of gastric cancer of cancer antigen peptide-specific TILs suitable for detection and clonal expansion is not a rule, because in up to $15 \%$ of our gastric cancer patients it was not possible to isolate and to expand any GCAA peptide-specific $\mathrm{T}$ cell clone, in spite of their appropriate HLA-A02 and/or HLA-A24 alleles. The simplest explanation for this failure is that a specific $\mathrm{T}$ cell response against the tumor antigens was missing or extremely poor in such patients because they were made somehow 'tolerant' to their gastric cancer antigens. However, the mechanisms responsible for such an anergic or tolerant state to gastric cancer remain unclear.

Using GCAA peptide-pulsed ${ }^{51} \mathrm{Cr}$-labeled autologous EBV-B cells as targets, we could demonstrate that all the $\mathrm{CD}^{+}$and $94 \%$ of $\mathrm{CD}^{+}$peptide-specific TIL-derived clones were equipped with the cytotoxic machinery required for the lysis of target cells. Furthermore, upon mitogen activation, $81 \%$ of the GCAA peptide-specific TIL clones were able to induce apoptosis in target cells by FasFasL interaction.

Taken together these results confirm that the TILderived clones specific for GCAA peptides are able to express a cancer peptide-specific cytotoxic activity, which may represent an important pre-requisite for effective gastric cancer immunotherapy $[29,44]$.

In the second part of the study, we analyzed whether T cells obtained from the peripheral blood of patients with gastric adenocarcinoma might have similar effector functions to those of TILs obtained from the gastric neoplastic lesions of the same patients. The presence of $\mathrm{T}$ cells specific for GCAA peptides in the peripheral blood has been documented in $14(70 \%)$ out of the 20 patients with gastric cancer. For the six gastric cancer patients in which GCAA peptide-specific $\mathrm{T}$ cells were not detectable in the peripheral blood, we suspect that their number was too small and below the sensitivity of the methods used or that virtually all the GCAA peptide-specific T cells homed into the neoplastic tissue, without consistent recirculation to the periphery. Of interest is the observation that among the six patients apparently lacking peptide-specific $\mathrm{T}$ cells in their peripheral blood, there were three patients (1.BB, 7.CS and 16.MG) in which we were unable to isolate and expand TIL-derived $\mathrm{T}$ cell clones specific for GCAA peptides, suggesting that a number of gastric cancer patients can indeed lack a cancer-specific $\mathrm{T}$ cell response, as already suggested in recent studies [18, 31].

Finally, we assessed the cytokine profile of GCAA peptide-specific $\mathrm{T}$ cells isolated from the peripheral blood of gastric cancer patients, and for each patient single GCAA peptides were used to induce specific $T$ cell lines which have been subsequently studied by intracytoplasmic cytofluorometric analysis. In most of the patients (16 out of 20 ) we obtained GCAA peptide-specific $\mathrm{T}$ cell lines that, upon stimulation with the specific peptide, included a quite high number of $\mathrm{T}$ cells expressing intracytoplasmic IFN- $\gamma$, whereas $T$ cells positive for intracytoplasmic IL-4 were very few or missing. These data support the notion that the majority of both gastric-derived and circulating $\mathrm{T}$ cells specific for gastric cancer antigens tend to express a Th1 or Tc1 profile. In addition, the production of cytokines was induced by the identical GCAA peptides that were able to evoke a specific $\mathrm{T}$ cell response at intra-tumor level of the same patients.

Since in none of the three patients (1.BB, 7.CS and 16.MG) apparently lacking GCAA peptide-specific TILs, in vitro stimulation with cancer peptides failed to generate GCAA peptide-specific $\mathrm{T}$ cell lines, we favor the hypothesis that those patients were actually unable to raise a $\mathrm{T}$ cell immune response against their gastric adenocarcinoma. On the other hand, the pre-vaccination screening proposed by some studies [44] before generating peptides to be used for anti-tumor vaccination can explain some of the negative responses that are not caused by a lack of immune response to cancer, but would be due to a small number of specific $\mathrm{T}$ cells circulating in the body.

According to our in vitro data, almost all the TILderived $\mathrm{T}$ cell clones isolated from gastric tumors showed a strong cytotoxic activity, which, however, was not effective in vivo to block the growth and the progression of their gastric cancer. A possible explanation of this discrepancy is that the in vivo conditions of activation of cancer antigenspecific $\mathrm{T}$ cells are quite different from those achieved in vitro, in which hampering of $\mathrm{T}$ cell response by regulatory $\mathrm{T}$ cells, immunosuppressive cytokines or other suppressive mechanisms are missing. Indeed, gastric cancer cells could inactivate the $\mathrm{T}$ cell cytotoxic activity through various 
mechanisms, such as tumor escape, production of blocking factors of the $\mathrm{T}$ cell response $[22,32]$ or through inappropriate recruitment of regulatory $\mathrm{T}$ cells [15]. In the case of a negative direct action of the tumor cells on the $\mathrm{T}$ cell response, also immunotherapeutic vaccination would have poor chance to be effective [9].

This study provided evidence that the majority of patients with gastric adenocarcinoma host in their neoplastic tissue a $\mathrm{T}$ cell response specific for MHC-class I restricted peptides belonging to tumor-associated antigens. In agreement with previous studies [28] that correlated the peptide-specific IgG levels in postvaccination sera with prolonged survival in advanced cancer patients vaccinated with peptides, we have demonstrated that a T cell GCAA peptide-specific response is also detectable in the peripheral blood, suggesting that TIL can recirculate in the periphery. There are however some exceptions, i.e., patients who apparently lack a $\mathrm{T}$ cell response to neoplastic antigens in their peripheral blood, in spite of the presence of cancer antigen-reactive $T$ cells within the cancer tissue. Finally, there are a few patients who apparently lack cancer antigenreactive $\mathrm{T}$ cells in either the tumor or the periphery.

Even though in most of the patients with gastric adenocarcinoma, a specific Th1/Tc1 cytotoxic T cell response to cancer antigen peptides was detectable, their capacity of hampering tumor cell growth was actually poor and ineffective in vivo. However, if the cancer peptide-specific Th1/ Tc1 response would be enhanced by vaccination with the appropriate cancer peptides or by injection of autologous GCAA peptide-specific $\mathrm{T}$ cells expanded in vitro, tumor cell killing in vivo might become reasonably achievable.

Acknowledgments We wish to thank Istituto Superiore di Sanità, Ente Cassa di Risparmio di Firenze and Italian Ministry of University and Research for their support of our studies.

\section{References}

1. Cunningham D, Allum WH, Stenning SP, Thompson JN, Van de Velde CJ, Nicolson M, Scarffe JH, Lofts FJ, Falk SJ, Iveson TJ, Smith DB, Langley RE, Verma M, Weeden S, Chua YJ (2006) MAGIC trial participants perioperative chemotherapy versus surgery alone for resectable gastroesophageal cancer. N Engl J Med 355:11-20

2. D'Elios MM, Manghetti M, Almerigogna F, Amedei A, Costa F, Burroni D, Baldari CT, Romagnani S, Telford JL, Del Prete G (1997) Different cytokine profile and antigen-specificity repertoire in Helicobacter pylori-specific T cell clones from the antrum of chronic gastritis patients with or without peptic ulcer. Eur J Immunol 27:1751-1755

3. D'Elios MM, Amedei A, Manghetti M, Costa M, Baldari CT, Quazi AS, Telford JL, Romagnani S, Del Prete G (1999) Impaired T-cell regulation of B-cell growth in Helicobacter pylori-related gastric low-grade MALT lymphoma. Gastroenterology 117:1105-1112

4. D'Elios MM, Bergman MP, Azzurri A, Amedei A, Benagiano M, De Pont JJ, Cianchi F, Vandenbroucke-Grauls CM, Romagnani S,
Appelmelk BJ, Del Prete G (2001) H(+), K(+)-atpase (proton pump) is the target autoantigen of Th1-type cytotoxic $\mathrm{T}$ cells in autoimmune gastritis. Gastroenterology 120:377-386

5. Darrow TL, Abdel-Wahab Z, Quinn-Allen MA, Seigler HF (1996) Recognition and lysis of human melanoma by a CD3+, CD4+, CD8- T-cell clone restricted by HLA-A2. Cell Immunol 172:5259

6. Del Prete G, De Carli M, Ricci M, Romagnani S (1991) Helper activity for immunoglobulin synthesis of T helper type I (Thl) and Th2 human T cell clones: the help of Thl clones is limited by their cytolytic capacity. J Exp Med I74:809-813

7. Del Prete G, De Carli M, Mastromauro C, Biagiotti R, Macchia D, Falagiani P, Ricci M, Romagnani S (1991) Purified protein derivative of Mycobacterium tuberculosis and excretory-secretory antigen(s) of Toxocara canis expand in vitro human T cells with stable and opposite (type $1 \mathrm{~T}$ helper or type $2 \mathrm{~T}$ helper) profile of cytokine production. J Clin Invest 83:346-350

8. Del Prete G, De Carli M, D’Elios MM, Maestrelli P, Ricci M, Fabbri L, Romagnani S (1993) Allergen exposure induces the activation of allergen-specific Th2 cells in the airway mucosa of patients with allergic respiratory disorders. Eur J Immunol 23:1445-1449

9. Elkord E, Hawkins RE, Stern PL (2008) Immunotherapy for gastrointestinal cancer: current status and strategies for improving efficacy. Expert Opin Biol Ther 8:385-395

10. El-Omar EM, Carrington M, Chow WH, McColl KE, Bream JH, Young HA, Herrera J, Lissowska J, Yuan CC, Rothman N, Lanyon G, Martin M, Fraumeni JF Jr, Rabkin CS (2000) Interleukin-1 polymorphisms associated with increased risk of gastric cancer. Nature 404:398-402

11. Ferlay J, Autier P, Boniol M, Heanue M, Colombet M, Boyle P (2007) Estimates of the cancer incidence and mortality in Europe in 2006. Ann Oncol 18:581-592

12. Ge Q, Holler PD, Mahajan VS, Nuygen T, Eisen HN, Chen J (2006) Development of CD4+ T cells expressing a nominally MHC class I-restricted T cell receptor by two different mechanisms. Proc Natl Acad Sci USA 103:1822-1827

13. Gomi S, Nakao M, Niiya F, Imamura Y, Kawano K, Nishizaka S, Hayashi A, Sobao Y, Oizumi K, Itoh K (1999) A cyclophilin B gene encodes antigenic epitopes recognized by HLA-A24-restricted and tumor-specific cytotoxic $\mathrm{T}$ lymphocytes. J Immunol 163:4994-5004

14. RC IA (1994) IARC monograph on the evaluation of carcinogenic risks to humans: Schistosomes, Liver Flukes and Helicobacter pylori, vol 16. IARC, Lyon

15. Ichihara F, Kono K, Takahashi A, Kawaida H, Sugai H, Fujii H (2003) Increased populations of regulatory $T$ cells in peripheral blood and tumor-infiltrating lymphocytes in patients with gastric and esophageal cancers. Clin Cancer Res 9:4404-4408

16. Imai N, Harashima N, Ito M, Miyagi Y, Harada M, Yamada A, Itoh K (2001) Identification of Lck-derived peptides capable of inducing HLA-A2-restricted and tumor-specific CTLs in cancer patients with distant metastases. Int J Cancer 94:237-242

17. Ito M, Shichijo S, Tsuda N, Ochi M, Harashima N, Saito N, Itoh K (2001) Molecular basis of T cell-mediated recognition of pancreatic cancer cells. Cancer Res 61:2038-2046

18. Kaper T, Looger LL, Takanaga H, Platten M, Steinman L, Frommer WB (2007) Nanosensor detection of an immunoregulatory tryptophan influx/kynurenine efflux cycle. PLoS Biol 5:e257

19. Kawano K, Gomi S, Tanaka K, Tsuda N, Kamura T, Itoh K, Yamada A (2000) Identification of a new endoplasmic reticulumresident protein recognized by HLA-A24-restricted tumor infiltrating lymphocytes of lung cancer. Cancer Res 60:3550-3558

20. Kelley JR, John M (2003) Duggan Gastric cancer epidemiology and risk factors. J Clin Epidemiol 56:1-9

21. Kono K, Takahashi A, Sugai H, Fujii H, Choudhury AR, Kiessling R, Matsumoto Y (2002) Dendritic cells pulsed with 
HER-2/neu-derived peptides can induce specific T-cell responses in patients with gastric cancer. Clin Cancer Res 8:3394-3400

22. Kroemer G, Pouyssegur J (2008) Tumor cell metabolism: cancer's Achilles' heel. Cancer Cell 13:472-482

23. Liakakos T, Roukos DH (2008) More controversy than ever-challenges and promises towards personalized treatment of gastric cancer. Ann Surg Oncol 15:956-960

24. Marchall BJ, Windsor HM (2005) The relation of Helicobacter pylori to gastric adenocarcinoma and lymphoma: pathophysiology, epidemiology, screening, clinical presentation, treatment, and prevention. Med Clin North Am 89:313-344

25. Mayne ST, Risch HA, Dubrow R, Chow WH, Gammon MD, Vaughan TL, Farrow DC, Schoenberg JB, Stanford JL, Ahsan H, West AB, Rotterdam H, Blot WJ, Fraumeni JF Jr (2001) Nutrient intake and risk of subtypes of esophageal and gastric cancer. Cancer Epidemiol Biomarkers Prev 10:1055-1062

26. Minami T, Matsueda S, Takedatsu H, Tanaka M, Noguchi M, Uemura H, Itoh K, Harada M (2007) Identification of SART3-derived peptides having the potential to induce cancer-reactive cytotoxic T lymphocytes from prostate cancer patients with HLA-A3 supertype alleles. Cancer Immunol Immunother 56:689-698

27. Mine T, Gouhara R, Hida N, Imai N, Azuma K, Rikimaru T, Katagiri K, Nishikori M, Sukehiro A, Nakagawa M, Yamada A, Aizawa H, Shirouzu K, Itoh K, Yamana H (2003) Immunological evaluation of CTL precursor-oriented vaccines for advanced lung cancer patients. Cancer Sci 94:548-556

28. Mine T, Sato Y, Noguchi M, Sasatomi T, Gouhara R, Tsuda N, Tanaka S, Shomura H, Katagiri K, Rikimaru T, Shichijo S, Kamura T, Hashimoto T, Shirouzu K, Yamada A, Todo S, Itoh K, Yamana H (2004) Humoral responses to peptides correlate with overall survival in advanced cancer patients vaccinated with peptides based on pre-existing, peptide-specific cellular responses. Clin Cancer Res 10:929-937

29. Mochizuki K, Sato Y, Tsuda N, Shomura H, Sakamoto M, Matsuura K, Ushijima K, Maeda Y, Katagiri K, Yamada A, Todo S, Kamura T, Harada M, Itoh K (2004) Immunological evaluation of vaccination with pre-designated peptides frequently selected as vaccine candidates in an individualized peptide vaccination regimen. Int J Oncol 25:121-131

30. Moretta A, Pantaleo G, Moretta L, Cerottini JC, Mingari MC (1983) Direct demonstration of the clonogenic potential of every human peripheral blood T cell: clonal analysis of HLA-DR expression and cytolytic activity. J Exp Med 157:743-751

31. Muller AJ, DuHadaway JB, Donover PS, Sutanto-Ward E, Prendergast GC (2005) Inhibition of indoleamine 2,3-dioxygenase, an immunoregulatory target of the cancer suppression gene Bin1, potentiates cancer chemotherapy. Nat Med 11:312-319

32. Nagaraj S, Gabrilovich DI (2008) Tumor escape mechanism governed by myeloid-derived suppressor cells. Cancer Res 68:2561-2563

33. Naito M, Komohara Y, Ishihara Y, Noguchi M, Yamashita Y, Shirakusa T, Yamada A, Itoh K, Harada M (2007) Identification of Lck-derived peptides applicable to anti-cancer vaccine for patients with human leukocyte antigen-A3 supertype alleles. Br J Cancer 97:1648-1654

34. Nakao M, Shichijo S, Imaizumi T, Inoue $Y$, Matsunaga $K$, Yamada A, Kikuchi M, Tsuda N, Ohta K, Takamori S, Yamana H, Fujita H, Itoh K (2000) Identification of a gene coding for a new squamous cell carcinoma antigen recognized by the CTL. J Immunol 164:2565-2574

35. Naumann M, Crabtree JE (2004) Helicobacter pylori-induced epithelial cell signaling in gastric carcinogenesis. Trends Microbiol 12:29-36

36. Niiya F, Nishizaka S, Matsunaga K, Koufuji K, Mori M, Katai H, Yamana H, Itoh K (2000) Expression of SART3 tumor-rejection antigen in gastric cancers. Jpn J Cancer Res 91:337-342
37. Nishimura MI, Avichezer D, Custer MC, Lee CS, Chen C, Parkhurst MR, Diamond RA, Robbins PF, Schwartzentruber DJ, Rosenberg SA (1999) MHC class I-restricted recognition of a melanoma antigen by a human CD4+ tumor infiltrating lymphocyte. Cancer Res 59:6230-6238

38. Nishizaka S, Gomi S, Harada K, Oizumi K, Itoh K, Shichijo S (2000) A new tumor- rejection antigen recognized by cytotoxic T lymphocytes infiltrating into a lung adenocarcinoma. Cancer Res 60:4830-4837

39. Ocean AJ, Schnoll-Sussman F, Keresztes R, Chen X, Holloway S, Matthews N, Christos P, Mazumdar M, Wright J, Wadler S (2006) Phase II study of PS-341 (bortezomib) with or without irinotecan in patients (pts) with advanced gastric adenocarcinomas (AGA). J Clin Oncol (20 June Supplement): 14040

40. Ohyauchi M, Imatani A, Yonechi M, Asano N, Miura A, Iijima K, Koike T, Sekine H, Ohara S, Shimosegawa T (2005) The polymorphism interleukin 8-251 A/T influences the susceptibility of Helicobacter pylori related gastric diseases in the Japanese population. Gut 54:330-335

41. Peek RM, Blaser MJ (2002) Helicobacter pylori and gastrointestinal adenocarcinomas. Nat Rev Cancer 2:28-37

42. Rocco A, Nardone G (2007) Diet, $H$ pylori infection and gastric cancer: evidence and controversies. World $\mathrm{J}$ Gastroenterol 13:2901-2912

43. Roukos DH, Kappas AM (2005) Perspectives in the treatment of gastric cancer. Nat Clin Pract Oncol 2:98-107

44. Sato Y, Shomura H, Maeda Y, Mine T, Une Y, Akasaka Y, Kondo M, Takahashi S, Shinohara T, Katagiri K, Sato M, Okada S, Matsui K, Yamada A, Yamana H, Itoh K, Todo S (2003) Immunological evaluation of peptide vaccination for patients with gastric cancer based on pre-existing cellular response to peptide. Cancer Sci 94:802-808

45. Sato Y, Fujiwara T, Mine T, Shomura H, Homma S, Maeda Y, Tokunaga N, Ikeda Y, Ishihara Y, Yamada A, Tanaka N, Itoh K, Harada M, Todo S (2007) Immunological evaluation of personalized peptide vaccination in combination with a 5-fluorouracil derivative (TS-1) for advanced gastric or colorectal carcinoma patients. Cancer Sci 98:1113-1119

46. Shah MA, Ramanathan RK, Ilson DH, Levnor A, D'Adamo D, O'Reilly E, Tse A, Trocola R, Schwartz L, Capanu M, Schwartz GK, Kelsen DP (2006) Multicenter phase II study of irinotecan, cisplatin, and bevacizumab in patients with metastatic gastric or gastroesophageal junction adenocarcinoma. J Clin Oncol 24:5201-5206

47. Shichijo S, Nakao M, Imai Y, Takasu H, Kawamoto M, Niiya F, Yang D, Toh Y, Yamana H, Itoh K (1998) A gene encoding antigenic peptides of human squamouscell carcinoma recognized by cytotoxic T lymphocytes. J Exp Med 187:277-288

48. Somasundaram R, Robbins P, Moonka D, Loh E, Marincola F, Patel A, Guerry D, Herlyn D (2000) CD4(+), HLA class I-restricted, cytolytic T-lymphocyte clone against primary malignant melanoma cells. Int J Cancer 85:253-259

49. Vanhoefer U, Tewes M, Rojo F, Dirsch O, Schleucher N, Rosen O, Tillner J, Kovar A, Braun AH, Trarbach T, Seeber S, Harstrick A, Baselga J (2004) Phase I study of the humanized antiepidermal growth factor receptor monoclonal antibody EMD72000 in patients with advanced solid tumors that express the epidermal growth factor receptor. J Clin Oncol 22:175-184

50. Vergelli M, Hemmer B, Muraro PA, Tranquilli L, Biddison WE, Sarin A, McFarland HF, Martin R (1997) Human autoreactive $\mathrm{CD} 4+\mathrm{T}$ cell clones use perforin- or Fas/Fas ligand-mediated pathways for target cell lysis. J Immunol 158:2756-2761

51. Yang D, Nakao M, Shichijo S, Sasatomi T, Takasu H, Matsumoto H, Mori K, Hayashi A, Yamana H, Shirouzu K, Itoh K (1999) Identification of a gene coding for a protein possessing shared tumor epitopes capable of inducing HLAA24-restricted cytotoxic T lymphocytes in cancer patients. Cancer Res 59:4056-4063 